\title{
Nanosilver - does it have only one face?
}

\author{
Wirginia Likus¹, Grzegorz Bajor ${ }^{1}$ and Krzysztof Siemianowicz ${ }^{2 \varpi}$ \\ 1Department of Human Anatomy, Medical University of Silesia, Katowice, Poland; 2Department of Biochemistry, Medical University of Silesia, \\ Katowice, Poland
}

Silver nanoparticles (NPs) have at least one dimension of a particle smaller than $100 \mathrm{~nm}$ and contain 20-15,000 silver atoms. Due to its antibacterial activity nanosilver (NS) is used for medical purposes. NS particles can be obtained by various methods. Potentially, the best method of the NS synthesis for medical purposes is based on a brief flow of electric current between two silver electrodes placed in deionized water. It is accepted that the major antibacterial effect of silver is its partial oxidation and releasing silver ions, which interact with thiol groups of peptidoglicans of bacterial cell wall, and proteins of the cell membrane causing cell lysis. Silver ions can also bind to bacterial DNA preventing its replication and stopping synthesis of bacterial proteins. The rise in exposure to silver NPs has spurred interest into their toxicology. NS undergoes a set of biochemical transformations including accelerated oxidative dissolution in gastric acid, binding to thiol groups of serum and tissue proteins, exchange between thiol groups, sulfides and selenides, binding to selenoproroteins and photoreduction in skin to zerovalent metallic silver. Animal studies have shown that exposure to NS may lead to liver and spleen damage. NS can also stimulate an increased secretion of proinflammatory cytokines by monocytes. As a spectrum of NS applications is still growing, the complex evaluation of a safety of its use becomes an important task. This requires an elucidation of not only the influence of NS on human cells and organism, but also its biotransformation in organism and in environment.

Key words: silver nanoparticles, antibacterial activity, toxicology Received: 11 April, 2013; revised: 24 November, 2013; accepted: 05 December, 2013; available on-line: 16 December, 2013

\section{INTRODUCTION}

The story began in 1959 at the meeting of American Physical Society, when a Nobel Prize winner, Richard A. Frey, gave a lecture "There is plenty room at the bottom". He is considered as a father of the nanotechnology idea (Feynman, 1992). According to National Nanotechnology Institute, this field of science comprises research, and development aimed at noticing, comprehension, measuring, and manipulating the matter at a level of atoms and molecules (Scott, 2005). A word "nano" originates from Greek and means "dwarf". Reducing the overall dimensions of a single particle to nanoscale changes its properties and gives it unique physical, chemical and biological features. $100 \mathrm{~nm}$ is a threshold dimension. Beneath this value the relation between a surface of a particle to its mass is big enough to alter the properties of such particle. Ultrasmall particle size leads to ultralarge area per mass, where large population of at- oms are in immediate contact with ambience and readily available for reaction. At the nanoscale particles exhibit different physical, optical and chemical properties owing to the dominant of quantum mechanics (Martinez-Gutrierrez et al., 2010; Lok et al., 2007; Martinez-Gutrierrez et al., 2012; Chen \& Schluesener, 2008).

Antibacterial properties of silver have been known since ancient times. In ancient Egypt silver bars were put into water, which was drunk as a medicine for ulcers. Food and wine were stored in silver vessels in order to prevent them from getting spoilt. Soldiers in Roman legions used to put silver coins on their wounds to accelerate their healing. In Mead Ages reach people were in the habit of giving their children silver spoons to suck as a protection against various diseases. Furthermore, a silver powder was administered orally as a medicine (Russell \& Hugo, 1994).

In 1884 German obstetrician, C.S.F. Crede administered $1 \%$ silver nitrate solution to prevent Gonococcal conjunctivitis in neonates. This was probably the first scientifically documented usage of silver in medicine (Russell \& Hugo, 1994). Chemical compounds containing silver were the main weapon against infections during the World War 2. Irreversible pigmentation of skin and eyes resulting from the deposition of silver compounds led to their withdrawal as antibacterial agents (Russell \& Hugo, 1994; Spencer et al., 1980).

Silver particles having at least one dimension, which is less than $100 \mathrm{~nm}$ containing 20-15000 silver atoms, are termed nanosilver (NS) or silver nanoparticles (NPs). They should not be confused with nanocrystals, nanosferes, or colloidal silver. The most important difference between NPs and nanocrystals is that nanocrystal is a crystalline nanoparticle or any singlecrystalline nanoparticle with at least one dimension not larger than $100 \mathrm{~nm}$. Nanocrystal can be also definied as a nanoparticle with any kind of crystalline structure. By contrast, NPs do not have to posses any crystalline structure (Chen \& Schluuesener, 2008; Sun \& Xia, 2002; Xu et al. 2008; Burt et al. 2005). Nanocrystals, nanosferes or colloidal silver is not discussed in this paper.

\footnotetext{
e-mail: ksiem@mp.pl

Abbreviations: $\left[\mathrm{Ag}\left(\mathrm{NH}_{3}\right)_{2}\right]^{+}$, diamminesilver ion; Ag, silver; APTT, activated partial thromboplastin time; BMP-2, bone morphogenetic protein-2; EC20, the highest tested concentration causing less than $20 \%$ reduction in weight; HIV-1, human immunodeficiency virus-1; IL-10, interleukin-10; IL-6, interleukin-6; MMPs, matrix metalloproteinases; NPs, nanoparticles; NS, nanosilver; OmpA, outer membrane protein $\mathrm{A}$; OmpC, outer membrane protein $\mathrm{C}$; OmpF, outer membrane protein F; PLGA, poly(lactic-coglycolic) acid; PT, prothrombin time; PVP, poly(N-vinyl)-2-pyrolidone; TNF- $\alpha$, tumor necrosis factor $\alpha$; TNF- $\beta$, tumor necrosis factor $\beta$; UV, ultraviolet
} 
Table 1. Methods of NS synthesis.

\begin{tabular}{l} 
Methods of NS synthesis \\
\hline $\begin{array}{l}\text { Reduction of nitrate by a reducing agent e.g. sodium borohy- } \\
\text { drate }\end{array}$ \\
Photoreduction of nitrate by UV light \\
Synthesis using microorganisms \\
Reduction of nitrate by gamma radiation in a presence of chi- \\
tosan \\
Synthesis of peptide-coated NS \\
Brief flow of electric current between two silver electrodes in \\
deionized water
\end{tabular}

\section{NANOSILVER SYNTHESIS}

There are many methods of NS synthesis, however, not all of them allow to obtain NS particles for biomedical applications (Table 1). The most often used method is a reduction of silver nitrate using either a reducing agent, e.g. sodium borohydride, or a photoreduction via UV light (Sato-Berru et al., 2009; Courrol et al., 2007). During these reactions silver ion $\left(\mathrm{Ag}^{+}\right)$ receiving an electron from the reducing agent reverts to its metallic form $\left(\mathrm{Ag}^{0}\right)$ which clusters to form NS. Copping agents, such as citrate or starch, are used to prevent aggregation and agglomeration of NPs. Each cluster contains between 100 and 1000 atoms of silver. NS can be also sythetised by the use of various species of bacteria e.g. Staphylococcus aureus and fungi (Shahverdi et al., 2007; Shaligram et al., 2009). These microorganisms are the source of enzymes and they reduce such compounds like hydrochinons. Other method uses chitosan obtained from microorganisms. Silver nitrate is added dropwise to chitosan dissolved in acetic acid. Silver ions in this solution are reduced by gamma radiation and stabilized by chitosan (Reicha et al., 2012). Another method is based on photoreduction of aqueous solution of $\left[\mathrm{Ag}\left(\mathrm{NH}_{3}\right)_{2}\right]^{+}$by UV light in the presence of poly $(\mathrm{N}$-vinyl)-2-pyrolidone (PVP). This method allows to obtain very small NPs of 4-6

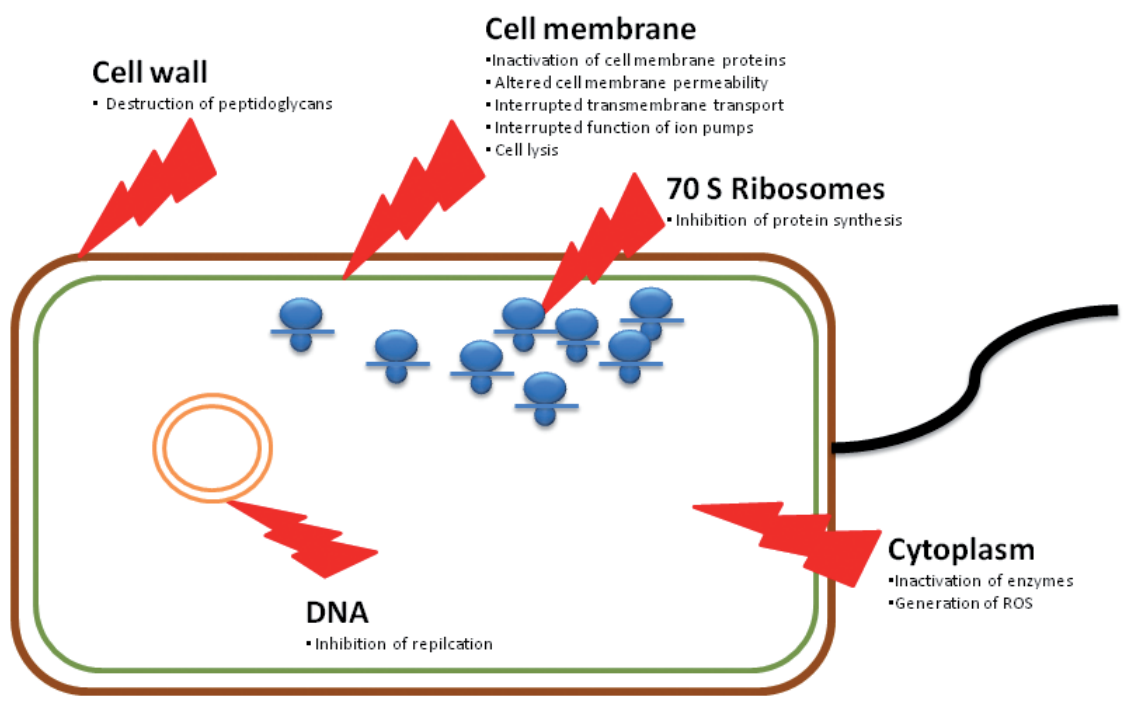

Figure 1. Mechanisms of the antibacterial activity of nanosilver (ROS, reactive oxygen species; $70 \mathrm{~S}, 70$ Svedberg (sedimentation) units). Detailed explanation can be found in the text. nm, which may be too small for medical purposes (Vigneshwaran et al., 2006).

The methods mentioned so far have some disadvantages. They do not allow for the precise control of NPs size resulting in a wide range of size of obtained NPs. The use of chitosan may alter the properties of NS. Graf et al. (2009) proposed a method of synthesis of peptide-coated silver NPs. This method was aimed at reducing the toxicity of NS, however peptide coated NS can aggregate in response to changes of $\mathrm{pH}$. Acidic $\mathrm{pH}$, which may occur at a place of pathology in human organism, e.g. inflammation, may cause agglomeration of peptide-coated NS, and can lead to occlusion of capillary blood vessels. This method of NS synthesis has another disadvantage. Peptide sequences can be immunogenic and trigger unwanted immune response (Chaloupka et al., 2010).

Potentially, the best method of the synthesis of NS for medical purposes is based on a brief flow of electric current between two silver electrodes placed in deionized water. An application of high voltage causes silver atoms to evaporate from the electrodes and condense back into aqueous NS. As no chemicals are used in this method, NS does not contain toxic residues or contaminations (Xu et al., 2008).

\section{MECHANISMS OF NANOSILVER'S ANTIBACTERIAL ACTION}

NPs possessing "altered" physical, chemical or optic properties may present a wide spectrum of their action (Fig. 1). Medicine knows the influence of NS on bacterial cells, fungi and viruses. NS can be useful against hundreds of bacterial species and theoretically, there is no problem of bacterial resistance like in case of antibiotic therapy. However, some researchers point out that in case of long term usage of NS there is a possibility of generation NS-resistant species of bacteria (Silver, 2003; Radzig et al., 2013; Lok et al., 2008).

It is supposed, that in aqueous solution NS releases silver ions, which are responsible for its antibacterial properties. However, a comparative study of few silver salts (nitrate, citrate and chloride) revealed, that NS particles have higher antibacterial potency than free silver ions (Morones et al., 2005; Shrivastawa et al., 2007; Yamanaka et al., 2005).

Cystein is a compound of the bacterial wall. This aminoacid posses reactive thiol groups -SH. Silver ions interact with cysteine residues leading to protein inactivation. Apart from sulfur, silver has a high affinity to phosphorus as well. Forming complexes with compounds containing these elements in cell wall, silver can alter their activity (Gordon et. al., 2010). Deposition of silver NPs in the bacterial cell surface can affect cell membrane permeability. NS can destroy both bacterial cell 


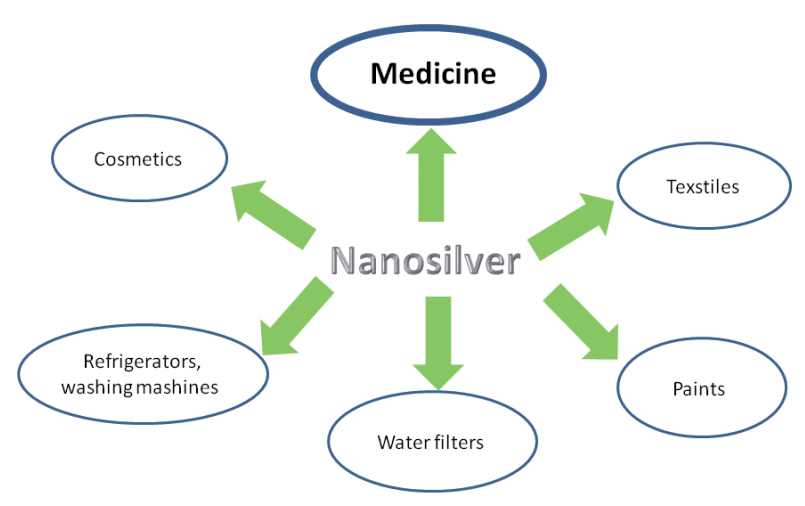

Figure 2. Various applications of nanosilver.

wall and cell membrane as well. It may lead to disturbances in transporting of ions and other substances between bacterial cell and its surrounding. The diminished activity of cell membrane sodium/potassium pumps results in water flux into bacteria cell and an enlargement of the cell volume (Semeykina \& Skulachev, 1990). NS can destruct a cell membrane and lead to bacterial cell lysis. Silver ions can penetrate into a bacterial cell causing a damage of its intracellular structures. A denaturation of ribosomes leads to the inhibition of protein synthesis (Jung et al., 2008; Bury \& Wood, 1999; Solioz \& Odermatt, 1995 \& Morones et al., 2005).

Silver ions can bind to the bases constructing DNA. This condensation with DNA leads to its inability to replicate preventing the bacterial reproduction. NS particles binding to bacterial wall create a coat disrupting moves of bacterial flagella. This multifaceted antibacterial activity of silver and NS is a key to low bacterial resistance rates. The antibacterial action of silver ions and NS starts with the binding to peptidoglicans of bacterial cell wall. Mammalian cells do not poses cell wall covering cell membrane. However, other mechanisms of NS action can affect both bacterial and human cells. The next mode of NS action uses its catalytic properties of generating free protons. They interact with disulfur bonds breaking them and leading to the disfunction of integral proteins of outer cell membrane, such as OmpA, $\mathrm{OmpC}, \mathrm{OmpF}$, which are responsible for interactions between bacteria and their environment, stability of bacterial cells, or binding various substrates (Lok et al., 2008; Ratsig et al., 2009).

Silver blocks some metabolic reactions taking place in cells. Silver combines with thiol residues of enzymes in-

Table 2. Toxicity of NS.

\begin{tabular}{l}
\hline Toxicity of NS \\
\hline Argyria \\
Oxidation of NS and ion release in digestive tract and uptake of these ions into blood \\
Binding of silver ions distributed by circulating blood to thiol groups of enzymes \\
Binding of silver to sulphides \\
Skin inflammatory response \\
Possible liver and spleen damage \\
Possible induction of proinflammatory response \\
Influence on coagulation \\
Possible cytotoxic effect to monocytes \\
Accumulation in brain
\end{tabular}

activating them. NS induces production of reactive oxygen species, which also takes part in a destruction of bacterial cell (Lok et al., 2007). NS also influences the cell wall of fungi, and interacts with proteins of proteinolipid core of viruses (e.g. HIV-1) (Panácek et al., 2009; Lara et al., 2010; Elechiguera et al., 2005).

\section{MEDICAL APPLICATIONS OF NANOSILVER}

Due to its strong antibacterial properties, NS has a wide spectrum of medical and paramedical applications as well (Fig. 2 and Table 3). NS is used as an addition to various products, which should poses antibacterial properties. NS is a component of paints used to cover walls of hospital wards and operating rooms. It is also used to impregnate clothes. NS used in production of socks was to reduce odors (Benn \& Westerhoff, 2008). NS was also added to a variety of cosmetic products for everyday hygiene, like soap, shampoos, deodorants, gels, and creams (Drake \& Hazelwood, 2005; Lee et al., 2007; Vigneshwaran et al., 2007; Walser et al., 2011).

Medical products have given a wide spectrum for the use of NS. It is used as an addition to protective clothes, mattresses, bed clothes, gloves, syringes, masks, and respirator tubes. The efficacy of these uses of NS is estimated even as $99 \%$. A next field where NS has been introduced is a protection of infections of wounds, burnings, ulcers and pemphigus. Creams with solutions of silver nitrate have been used to accelerate healing of burns for a long time (Singh \& Singh, 2012; Cho et al., 2002; Lee et al., 2002; Madhumati et al., 2010). Dressings or bandages contain polyethylene nets with NS particles with dimensions of 10-15 nm. The application of such dressings can accelerate the process of wound healing of three days. Some dressings contain chitosan to prevent an absorbtion of NS from the dressing and its accumulation in patient's organism. Anti-inflammatory properties of NS were evaluated in pigs with experimental dermatitis. Treatment with dressings containing NS resulted in a reduction of serum levels of proinflammatory molecules, tumor necrosis factor $\alpha$ and $\beta$ (TNF- $\alpha$ and TNF- $\beta$ ). There are three possible mechanisms of anti-inflammatory action of NS. A reduction of a release of proinflammatory cytokines, a reduction of a number of lymphocytes and mast cells, and the third one is the induction of apoptosis of the inflammatory cells. Matrix metalloproteinases (MMPs) play an important role in protracted ulcerations. Problems with healing of such ulcerations are connected with an overexpression of MMPs. Dressings containing NS can reduce production of MMPs. NS is also used in dentist seals and dentist dressings. These components contain NS connected with calcium phosphate (Huang et al., 2007; Lu et al., 2008; Yang et al., 2007; Wright et al., 2002).

NS is also used to cover surgical threads and tools (Saxena et al., 2011). Catheters introduced into veins to administer drugs and obtain blood samples, or monitor blood pressure in specific regions of circulatory system, are a potential gateway of infection. These catheters are covered with NS. This antibacterial protection is non toxic and can inhibit a growth of bacteria for at least 72 hours (Samuel \& 
Table 3. Medical applications of nanosilver.

\begin{tabular}{l}
\hline Medical applications of NS \\
Wound dressings \\
Surgical threads \\
Various implants \\
Catheters \\
Bone cement \\
Materials for bone regeneration \\
Dentist seals and dressings \\
Syringes \\
Gloves \\
Bed clothes and mattresses \\
Respirator tubes \\
\hline Wall paints \\
Protective gloves
\end{tabular}

Guggenbichler, 2004; Davenas et al., 2002; de Mel et al., 2012). Patients suffering from hydrocephalus often have implanted valve system containing catheters, which evacuate an excess of cerebrospinal fluid from brain chamber system to abdominal cavity. These catheters are a plausible gateway of bacterial infection spreading to central nervous system. Pseudomonas aeruginosa and Staphylococcus aureus are dangerous bacterial species, which may cause meningitis. The use of NS to cover the catheters introduced into brain chambers reduces this risk (Roe et al., 2008).

Orthopedics is a next branch of medicine where infections are dangerous and very difficult to treat. NS is used to cover various orthopedical implants as well as materials used for bone regeneration (Pishbin et al., 2013). Some researchers used complexes of bone morphogenetic protein-2 (BMP-2) and NS particles with dimensions between 20 and $40 \mathrm{~nm}$, which were placed on poly(lactic-coglycolic) acid (PLGA). They presented strong antibacterial properties. NS in these complexes did not present cytotoxic properties and did not inhibit an osteoinductive influence of BMP-2 on bones (Zheng et al., 2010). NS is also used as a component of bone cement to prevent development of bacterial infections (Alt et al., 2004). Complexes of connective tissue proteins, collagen, laminin or fibronectine and NS have been used to treat an experimental $10 \mathrm{~nm}$ break in rat ischiac nerve giving promising results (Ding et al., 2011).

Antibacterial properties of NS are used in production of drug and food packings (Tankhiwale et al., 2009).

\section{IS NANOSILVER TOXIC?}

Silver NPs have become increasingly prevalent in various consumer products as antibacterial agents. The number of products containing NS has grown more than 10 times between 2006 and 2011 (Stensberg et al., 2011). It is estimated that in 2015 more than 1000 ton of NS particles will be produced for use in commercial or industrial products (Stensberg et al., 2011). It is important to consider safety issues of the use of NS (Table 2). There are three fields where humans may be exposed to NS. Commercial products used in everyday life, such as water filters and water purificants, soap, deodorants, laundry detergents, room sprays, clothing, underwear, socks. The next field comprises various paramedical and medi- cal products. The third aspect, often underestimated, is the environment pollution with NS (Liang et al., 2010; Kiser et al., 2012; Wang et al., 2012; Benn et al., 2010; Benn \& Westerhoff 2008; Blaser et al., 2008; Kim et al., 2010).

For a long time NS has been considered as a quite safe antibacterial agent, and the only side effect of overdosage was an irreversible pigmentation of skin and/or eyes called argyria or argyrosis. Engineered nanomaterials can undergo profound transformation between the time of their synthesis, and reaching various tissues or intracellular structures. These changes may involve adsorbtion, chemical reactions, dissolution and aggregation influencing bioavailability, transport, accumulation and toxicity (Liu et al., 2012).

The ways of exposure to NS include ingestion, inhalation, dermal contact, wound surface application, and insertion or implantation of medical devices. NS is unstable to oxidation and releases ions through gradual reaction with dioxygen and protons. Biological fluids have a wide range of $\mathrm{pH}$. Liu et al. (2012) estimated the influence of $\mathrm{pH}$ on silver NPs dissolution. Acidic $\mathrm{pH}$ accelerated this process. In humans, this process takes place in stomach, where ingested NS is exposed to hydrochloric acid secreted there. Silver ions generated in digestive tract can be brought into blood stream through ion or nutrient uptake channels. However, the ability of silver particles to cross the gut epithelium is limited, so ion uptake seems to be the main route of silver absorbtion from gastrointestinal tract (Liu et al., 2012; Johnston et al., 2010). It is supposed, that silver ions may be transported by mechanism responsible for transport of sodium or copper ions (Bury \& Wood, 1999; Solioz \& Odermatt, 1995). In patients with argyria silver deposits in the connective tissue were found. It was also found that this deposits were collocated with sulphur and selenium. Silver deposits in patients with argyria are often placed in skin regions exposed to light. Majority of silver in circulation is predicted to be bound to thiol groups of proteins. Although silver has high binding affinity to these groups, it is easily exchangeable giving silver significant biomolecular mobility. Sulphides and selenides have higher binding affinities for silver, but their concentrations in biological fluids are lower. When silver complexes with thiol groups reach skin or near-skin region, it can be easily reduced by visible or UV light to metallic NS particles. This process results in an immobilization of silver as metallic NS. In this form silver has low particle diffusity and cannot undergo chemical thiol exchange reactions (Liu et al., 2012). These findings put a new light on a pathogenesis of an old side effect of a treatment with silver compounds, argyria, and explain why skin regions exposed to light are the favorite sites of pigmentation in argyria.

Although silver NPs have been for a long time considered as non toxic to mammals, recent years have given new evidence making us look more cautiously at NS. Korani et al. (2011) performed on genuine pigs a study of acute and chronic dermal toxicity of colloidal NS. Skin inflammatory response was detected in all experimental animals. Despite the fact that NS was applied only topically, these exposures led also to slight liver and spleen damage detected in histopathologic examinations. This experiment proves that NS can be absorbed by skin and distributed through the organism. Other researchers (Martinez-Gutrierez et al., 2012) evaluated an influence of NS on cultured human monocytes. NS induced secretion of proinflammatory cytokines, interleukin-6 and 10 (IL-6 and IL-10). These effects were observed 
at low concentrations of NS $(10 \mu \mathrm{g} / \mathrm{mL})$. In this experiment, small NS particles were used, majority of them did not exceed $30 \mathrm{~nm}$. The choice of small NPs, which are known to be more toxic, could have an important influence on observed results. As monocytes and macrophages constitute one of the main mediators of the immune response, these findings should be taken into consideration while estimating the safety of long term human exposure to NS. The same authors studied an influence of NS on coagulation of normal human plasma. NS did not influence the extrinsic pathway followed by prothrombin time (PT), but inhibited the extrinsic pathway of coagulation measured by activated partial thromboplastin time (APT'T). In a previous study, (Martinez-Gutrierez et al., 2010) they showed that cultured monocytes are sensitive to cytotoxic influence of NS when its concentration is greater than $5 \mu \mathrm{g} / \mathrm{mL}$. Other experiment showed that mice injected with silver NPs presented a decrease in platelet aggregation (Shrivastava et al., 2009). The influence of NS particles on presented aspects of coagulation system requires further studies and elucidation. Animal studies showed that inhalation of NS particles can lead to alveolar wall thickening and macrophage infiltration. However, silver NPs can be absorbed from lung alveoli and transported in blood to brain. It was confirmed in animal model that silver NPs injected into the blood stream can cross the blood-brain barrier and accumulate in brain. This deposition of NS can cause neuronal degeneration and necrosis (Sung et al., 2008; Takenaka et al., 2001; Tang et al., 2008).

Other aspect of NS toxicity is focused in its influence on neoplasmatic cells. Moaddab et al. (2011) observed that NS with very small particles, with average size of $4.5 \mathrm{~nm}$, presented a concentration-dependent toxicity for cultured osteoblast cancer cells. $\mathrm{IC}_{50}$ determined to $3.42 \mu \mathrm{g} / \mathrm{mL}$ suggested that these NS particles were more toxic to cancerous cells comparing to other heavy metal ions (Moaddab et al., 2011). NS was also reported as toxic to human glioblastoma cells (Asharani et al. 2009). This study also showed a genotoxicity of NS. Ahamed et al. (2008) evaluated an influence of two kinds of NS particles on mouse embryonic stem cells and mouse embryonic fibroblasts. Both uncoated NS with dimension of $25 \mathrm{~nm}$ and polysaccharide surface coated NS elicited genotoxicity. An increase in expression of p53 protein was detected 4 hours after exposition to NS. Also and upregulation of DNA damage repair protein Rad51 was detected. Both forms of NS induced also apoptosis. Polysaccharide coated NS particles exhibited more toxic influence than uncoated. These differences in severity of genotoxic influence of NS particles of the same dimension were probably caused by the fact, that uncoated particles agglomerated, what limited the surface area availability and access to membrane bound organelles (Ahamed et al., 2008). These results raise a question about consequences of long term, low level exposure to this kind of NS particles or NS at all. Shrivastava et al. (2012) evaluated the influence of NS and silver ions at subtoxic doses on selenium metabolism in cultured keratinocytes and human adenocarcinomic alveolar basal epithelium cells. Both NS and silver ions led to a significant decrease in incorporation of selenium into selenoproteins, such as glutathione peroxidase, thioredoxin reductase, or methionine sulfide reductase. These enzymes play vital role in the defence against oxidants, such as superoxide or peroxides. They contain selenocysteine at their active sites. This decrease in synthesis of selenoproteins is like to have significant implications in the defence against oxidative stress. Thioredoxin reductase plays also a crucial role in production of a reduced thioredixin for the ribonucleotide reductase, and thus DNA synthesis. The high affinity of silver for selenium leads not only to silver immobilization causing argyria, but also can lead to disturbances in DNA synthesis, increased oxidative stress in cell and damages of cell structures caused by reactive oxygen species (Shrivastava et al., 2012).

In 1939 Hill and Pillsbury evaluated the exposure limit above which the development of argyria could be expected. The threshold value was found to be the intake of $0.9 \mathrm{~g}$ of silver over the whole lifetime (Hill \& Pilsbury, 1939). Although this value was calculated more than 70 years ago, American modern drinking water standard for silver concentration (less than $100 \mu \mathrm{g} / \mathrm{L}$ ) is based on this value. Discussing the toxicology of silver one should consider a distinction between bulk metallic silver, NS and silver ions. American Conference of Governmental Industrial Hygienists has established separate thresholds limits values for metallic silver $\left(0.1 \mathrm{mg} / \mathrm{m}^{3}\right)$, and soluble compounds of silver $\left(0.01 \mathrm{mg} / \mathrm{m}^{3}\right)$ (Nowack et al., 2011). In 2010 it was estimated that about 320 tons of NS were produced and used worldwide each year (Nowack et al., 2011). Silver and NS released from various materials, especially from silver algicides and disinfectants used in swimming pools is discharged into sewer system, wastewater treatment plants and natural waters. Does it cause an increased risk of long time exposure to humans? Many of the aquatic species are several orders of magnitude more sensitive to silver than mammals and humans. For some of those organisms lethal concentration is only 1-5 $\mu \mathrm{g} / \mathrm{L}$ (Nowack et al., 2011). Daphnia magna, an aquatic invertebra, has focused the researchers' interest. It has been observed that this organism accumulates NS from aquous, as well as a foodborne exposure (Zhao \& Wang, 2011). Hoheisel et al. (2012) observed an increased toxicity of NS with decreasing particle size. However, both 96 hours and 7 days sublethal 20\% effective concentrations (EC20) were not significantly different for NS and silver ions. Interesting results were obtained by Shi et al. (2012). Comparison of toxicity of NS particles and silver ions to Tetrabymena pyriformis gave various results depending on conditions of the experiment. The toxicity of NS was higher than silver ions in the dark environment without light, but under the light condition the toxicity of NS decreased greatly. The presence or absence of light did not influence the toxicity of silver ions. The light irradiation could induce the enlargement of NS particles and formation of bulk agglomeration resulting in losing the properties of NPs and slowing the release of silver ions. NS is not only the product of industrial nanotechnology, but also a result of spontaneous formation in environment and biological systems following exposure to traditional forms of silver like silver nitrate. On the other hand, manufactured silver NPs released to the environment from various commercial products can agglomerate and lose the properties characterizing NPs (Liu et al., 2012).

\section{CONCLUDING REMARKS}

NS can have a wide spectrum of medical, paramedical and everyday use. Taking into consideration that in various environmental conditions silver can undergo spontaneous transformation leading either to creation of NS particles from silver ions, or agglomeration of NS into greater particles, sometimes it is difficult to demarcate the toxicity of traditional silver compounds and NS. The complete evaluation of safety of products containing NS 
requires an elucidation of not only the influence of NS on human cells and organism, but also its biotransformation in the organism and in the environment. Centuries ago Paracellsus said: "everything is a poison and nothing is a poison, it is only a matter of a dose". In case of NS it is a matter of both dose and particle size.

\section{REFERENCES}

Ahamed M, Karns M, Goodson M, Rowe J, Hussain SM, Schlager JJ et al. (2008) DNA damage response to different surface chemistry of silver nanoparticles in mammalian cells. Toxicol Appl Pharmacol 233: 404-410.

Alt V, Bechert T, Steinrücke P, Wagener M, Seidel P, Dingeldein E $e t$ al. (2004) An in vitro assessment of the antibacterial properties and cytotoxicity of nanoparticulate silver bone cement. Biomaterials 25: 4383-4391.

Asharani PV, Mun G, Low Kah, Hande MP, Valiyaveettil S (2009) Cytotoxicity and genotoxicity of silver nanoparticles in human cells. ACS Nano 3: 279-290.

Benn T, Cavanagh B, Hristovski K, Posner JD, Westerhoff P (2010) The release of nanosilver from consumer products used in the home. J Envir Qual 39: 1875-1882.

Benn TM, Westerhoff P (2008) Nanoparticle silver released into water from commercially available sock fabrics. Envir Sci Technol 42: 4133-4139.

Blaser SA, Scheringer M, Macleod M, Hungerbühier K (2008) Estimation of cumulative aquatic exposure and risk due to silver: contribution of nano-functionalized plastics and textiles. Sci Total Envir 390: 396-409.

Burt JL, Elechiguerra L, Reyes-Gasga J, Montejano-Carrizales JM, Jose-Yacaman M (2005) Beyond Archimedean solids: star polyhedral gold nanocrystals. J Cryst Growth 285: 681-691.

Bury NR, Wood CM (1999) Mechanism of branchial apical silver uptake by rainbow trout is via the proton-coupled $\mathrm{Na}(+)$ Channel. $\mathrm{Am}$ J Physiol 277: R1385-R1391.

Chaloupka K, Malam Y, Seifalian AM (2010) Nanosilver as a new generation of nanoproduct in biomedical applications. Trends in Biotechnology 28: 580-588.

Chen X, Schluesener HJ (2008) Nanosilver: a nanoproduct in medical application. Toxicol Lett 176: 1-12.

Cho YS, Lee JW, Lee JS, Lee JH, Yoon TR, Kuroyanagi Y et al. (2002) Hyaluronic acid and silver sulfadiazine-impregnated polyurethane foams for wound dressing application. J Mater Sci Mater Med 13: 861-865

Courrol LC, de Oliveira Silva FR, Gomes L (2007) A simple method to synthesize silver by photo-reduction. Colloids Surf. A: Physicochemical and Engineering Aspects 305: 5457.

Davenas J, Thévena d P, Philippe F, Arnaud MN (2002) Surface implantation treatments to prevent infection complications in short term devices. Biomol Eng 19: 263268.

Ding T, Lu WW, Zheng Y, Li ZY, Pan HB, Luo Z (2011) Rapid repair of rat sciatic nerve injury using a nanosilver-embedded collagen scaffold coated with laminin and fibronectin. Regen Med 6: 437-447.

Drake PL, Hazelwood KJ (2005) Exposure-related health effects of silver and silver compounds: a review. Ann Occup Hyg 49: 575-585.

Elechiguerra JL, Burt JL, Morones JR, Camacho-Bradago A, Gao X, Lara HH et al. (2005) Interaction of silver nanoparticles with HIV1. J Nanobiotechnology 3: 6 doi:10.1186/1477-3155-3-6; http://www. jnanobiotechnology.com/content/3/1/6.

Feynman RP (1992) There's plenty of room at the bottom. J Microelectromech Syst 1: 60-66.

Gordon O, Vig Slenters T, Brunetto PS, Villaruz AE, Sturdevant DE, Ott M et al. (2010) Silver coordination polymers for prevention of implant infection: thiol interaction, impact on respiratory chain enzymes, and hydroxyl radical induction. Antimicrob Agents Chemother 54: 4208-4218.

Graf P, Mantion A, Foelske A, Shkilnyy A, Masić A, Thünemann AF, Taubert A (2009) Peptide-coated silver nanoparticles: synthesis, surface chemistry, and $\mathrm{pH}$-triggered, reversible assembly into particle assemblies. Chemistry 15: 5831-5844.

Hill WR, Pillsbury DM. Argyria, the pharmacology of silver. The Williams \& Wilkins Co., Baltimore, MD, 1939.

Hoheisel SM, Diamond S, Mount D (2012) Comparison of nanosilver toxicity in Daphnia magma and Pimephales promelas. Environ Toxicol Chem 31: 2557-2563.

Huang Y, Li X, Liao Z, Zhang Z, Liu Q, Tang J et al. (2007) A randomized comparative trial between Acticoat and SD-Ag in the treatment of residual burn wounds, including safety analysis. Burns 33: $161-166$.

Johnston H J, Hutchison G, Christensen FM, Peters S, Hankin S, Stone V (2010) A review of the in vivo and in vitro toxicity of silver and gold particulates: particle attributes and biological mecha- nisms responsible for the observed toxicity. Crit Rev Toxicol 40: 328-346.

Jung WK. Koo HC, Kim KW, Shin S, Kim SH, Park YH (2008) Antibacterial activity and mechanism of action of the silver ion in Staphylococcus aureus and Escherichia coli. Appl Environ Microbiol 74: $2171-2178$

Kim B, Park CS, Murayama M, Hochella MF (2010) Discovery and characterization of silver sulfide nanoparticles in final sewage sludge products. Envir Sci Tecbnol 44: 7509-7514.

Kiser MA, Ladner DA, Hrislovski KD, Westerhoff PK (2012) Nanomaterial transformation and association with fresh and freeze-dried wastewater activated sludge: implications for testing protocol and envirimental fate. Envir Sci Tecbnol 46: 7046-7053.

Korani M, Rezayat SM, Gilani K, Bidgoli AS, Adeli S (2011) Acute and subchronic dermal toxicity of nanosilver in guinea pig. Int $\mathrm{J} \mathrm{Na}$ nomedicine 6: 855-862.

Lara HH, Ayala-Nuñez NV, Ixtepan-Turrent L, Rodriguez-Padilla C (2010) Mode of antiviral action of silver nanoparticles against HIV1. J Nanobiotechnology 8: 1; doi: 10.1186/1477-3155-8-1; http://www. jnanobiotechnology.com/content/8/1/1

Lee JE, Park JC, Lee KH, Oh SH, Suh H (2002) Laminin modified infection-preventing collagen membrane containing silver sulfadiazinehyaluronan microparticles. Artif Organs 26: 521-528.

Lee HY, Park HK, Lee YM, Kim K, Park SB (2007) A practical procedure for producing silver nanocoated fabric and its antibacterial evaluation for biomedical applications. Chem Commun (Camb) 28: 2959-2961.

Liang Z, Das A, Hu Z (2010) Bacterial response to a shock load of nanosilver in an activated sludge treatment system. Water Res 44: 5432-5438

Liu J, Wang Z, Liu FD, Kane AB, Hurt RH (2012) Chemical transformations of nanosilver in biological environments, ACS NANO 6: 9887-9899.

Lok CN, Ho CM, Chen R, He QY, Yu WY, Sun H et al. (2007) Silver nanoparticles: partial oxidation and antibacterial activities. J Biol Inorg Chem 12: 527-534.

Lok CN, Ho CM, Chen R, Tam PK, Chiu JF, Che CM (2008) Proteomic identification of the Cus system as a major determinant of constitutive Escherichia coli silver resistane of chromosomal origin. J Proteosome Res 7: 2351-2356.

Lu S, Gao W, Gu HY (2008) Construction, application and biosafety of silver nanocrystalline chitosan wound dressing. Burns 34: 623628.

Madhumati K, Sudheesh Kumar PT, Abhilash S, Sreeja V, Tamura $\mathrm{H}$ et al. (2010) Development of novel chitin/nanosilver composite scaffolds for wound dressing applications. J Mater Sci Mater Med 21: 807-813.

Martinez-Gutierrez F, Olive PL, Banuelos A, Orrantia E, Nino N, Morales Sanchez E et al. (2010) Synthesis, characterization, and evaluation of antimicrobial and cytotoxic effect of silver and titanium nanoparticles. Nanomedicine 6: 681-688.

Martinez-Gutierrez F, Olive PL, Banuelos A, Orrantia E, Nino N, Sanchez EM et al. (2010) Synthesis, characterization, and evaluation of antimicrobial and cytotoxic effect of silver and titanium nanonparticles. Nanomedicine 6: 681-688.

Martínez-Gutierrez F, Thi EP, Silverman JM, de Oliveira CC, Svensson SL, Hoek AV et al. (2012) Antibacterial activity, inflammatory response, coagulation and cytotoxicity effects of silver nanoparticles. Nanomedicine 3: 328-236.

de Mel A, Chaloupka K, Malam Y, Darbyshire A, Cousins B, Seifalian AM (2012) A silver nanocomposite biomaterial for blood-contacting implants. J Biomed Mater Res A 100: 2348-2357.

Moaddad S, Ahari H, Shahbazzadeh D, Motallebi AA, Anvar AA, Rahman-Nya JR et al. (2012) Toxicity study of nanosilver (Nanocid $囚$ ) on osteoblast cancer cell line. Int Nano Lett 1: 11-16.

Morones JR. Elechiguerra JL, Camacho A, Holt K, Kouri JB, Ramírez JT et al. (2005) The bactericidal effect of silver nanoparticles. Nanotechnology 16: 2346-2353.

Nowack B, Krug HF, Height M (2011) 120 years of nanosilver history: implications for policy makers. Environ Sci Tecbnol 45: 1177-1183.

PanácekA, Kolár M, Vecerová R, Prucek R, Soukupová J, Krystof V et al. (2009) Antifungal activity of silver nanoparticles against Candida spp. Biomaterials 31: 6333-6340.

Pishbin F, Mourino V, Gilchrist JB, McComb DW, Kreppel S, Salih V et al. (2013) Single-step electrochemical deposition of antimicrobial orthopaedic coatings based on a bioactive glass/chotosan/nano-silver composite svstem. Acta Biomater 9: 7469-7479.

Radtsig MA, Koksharova OA, Khmel' IA (2009) Antibacterial effects of silver ions: effect on gram-negative bacteria growth and biofilm formation. Mol Gen Mikrobiol Virusol 4: 27-31 (article in Russian).

Radzig MA, Nadtochenko VA, Koksharova OA, Kiwi J, Lipasova VA, Khmel IA (2013) Antibacterial effects of silver nanonoparticles on gram-negative bacteria: influence on the growth and biofilms formation, mechanism of action. Colloids Surf. B: Biointerfaces 102: 300-306. 
Reicha FM, Sarhan A, Abdel-Hamid MI, El-Sherbiny IM (2012) Preparation of silver nanoparticles in the presence of chitosan by electrochemical method. Carbohydrate polymers 89: 236-244.

Roe D, Karandikar B, Bonn-Savage N, Gibbins B, Roullet JB (2008) Antimicrobial surface functionalization of plastic catheters by silver nanoparticles. J Antimicrob Chemother 61: 869-876.

Russell AD, Hugo WB (1994) Antimicrobial activity and action of silver. Prog Med Chem 31: 351-370.

Samuel U, Guggenbichler JP Prevention of catheter-related infections: the potential of a new nano-silver impregnated catheter. Int J Antimicrob Agents 23: S75-S78.

Sato-Berru R. Redón R, Vázquez-Olmos A, Saniger JM (2009) Silver nanoparticles synthesized by direct photoreduction of metal salts. Application in surface-enhanced Raman spectroscopy. J Raman Spectrosc 40: 376-380.

Saxena S, Ray AR, Kapil A, Pavo-Djavid G, Leturner D, Gupta B, Meddahi-Pellé A (2011) Development of a new polypropylene-based suture: plasma grafting, surface treatment, characterization, and biocompatibility studies. Macromol Biosci 11: 373-382.

Scott NR (2005) Nanotechnology and animal health. Rev Sci Tech 24: $425-432$.

Shahverdi AR, Minaeian S, Shahverdi HR, Jamalifar H, Nohi A-A (2007) Rapid synthesis of silver nanoparticles using culture supernatants of Enterobacteria: a novel biological approach. Process Biochem 42: 919-923.

Semeykina AL, Skulachev VP (1990) Submicromolar $\mathrm{Ag}^{+}$increases passive $\mathrm{Na}^{+}$permeability and inhibits the respiration-supported formation of $\mathrm{Na}^{+}$gradients in Baccillus FTU vesicles. FEBS Lett 269: $69-72$.

Shaligram NS, Bule M, Bhambure R, Singhal RS, Singh SK, Szakacs G. et al. (2009) Biosynthesis of silver nanoparticles using aqueous extract from the compactin producing fungal strain. Process Biochem 44: 939-943.

Shi JP, Ma CY, Xu B, Zhang HW, Yu CP (2012) Effect of light on toxicity of nanosilver to Tetrahymena pyriformis. Environ Toxicol Chem 31: 1630-1638.

Shrivastava S, Bera T, Roy A, Singh G, Ramachandrarao P, Dash D (2007) Characterization of enhanced antibacterial effects of novel silver nanoparticles. Nanotechnology 18: 225103, doi: 10.1088/09574484/18/22/225103; http:// stacks.iop.org/Nano/18/225103

Shrivastava S, Bera T, Singh SK, Singh G, Ramachandrarao P, Dash D (2009) Characterization of antiplatelet properties of silver nanoparticles. ACS Nano 3: 1357-1364.

Silver S (2003) Bacterial silver resistance: molecular biology and uses and misuses of silver compounds. FEMS Microbiol Rev 27: 341-353.

Singh R, Singh D (2012) Radiation synthesis of PVP/alginate hydrogel containing nanosilver as wound dressing. J Mater Sci Mater Med 23: 2649-2658.

Solioz M, Odermatt A (1995) Copper and silver transport by CopBATPase in membrane vesicles of Enterococcus hirae. J Biol Chem 270: 9217-9221.

Spencer WH, Garron LK, Contreras F, Hayes TL, Lai C (1980) Endogenous and exogenous ocular and systemic silver deposition. Trans Ophtalmol Soc U K 100: 171-178.

Srivastava M, Singh S, Self WT (2012) Exposure to silver nanoparticles inhibits selenoprotein synthesis and the activity of thioredoxin reductase. Environ Health Perspect 120: 56-61.

Stensberg MC, Wei Q, McLamore ES, Porterfield DM, Wei A, Sepúlveda MS (2011) Toxicological studies on silver nanoparticles: challenges and opportunities in assessment, monitoring and imaging Nanomedicine (Lond) 6: 879-898.

Sun Y, Xia Y (2002) Shape-controlled synthesis of gold and silver nanoparticles. Science 298: 2176-2179.

Sung JH, Ji JH, Yoon JU, Kim DS, Song MY, Jeong J et al. (2008) Lung function changes in Sprague-Dawley rats after prolonged inhalation exposure to silver nanoparticles. Inhal Toxicol 20: 567-574.

Takenaka S, Karg E, Roth C, Schulz H, Ziesenis A, Heinzmann U et al. (2001) Pulmonary and systemic distribution of inhaled ultrafine silver particles in rats. Environ Health Persp 109: 547-551.

Tang J, Xiong L, Wang S, Xiong L, Wang S, Wang J, Liu L, Li J et al. (2008) Influence of silver nanoparticles on neurons and bloodbrain barrier via subcutaneous injection in rats. Appl Surf Sci 255: 502-504.

Tankhiwale R, Bajpa SK (2009) Graft copolymerization onto cellulosebased filter paper and its further development as silver nanoparticles loaded antibacterial food-packing material. Colloids Surf B Biointerfaces 69: 164-168.

Vigneshwaran N, Nachane RP, Balasubramanya RH, Varadarajan PV (2006) A novel one-pot 'green' synthesis of stable silver nanoparticles using soluble starch. Carbohydr Res 341: 2012-2018.

Vigneshwaran N, Kathe AA, Varadarajan PV, Nachane RP, Balasubramanya RH (2007) Functional finishing of cotton fabrics using silver nanonparticles. J Nanosci Nanotechnol 7: 1893-1897.

Wang Y, Westerhoff P, Hristovski KD (2012) Fate and biological effects of silver, titanium dioxide, and C60 (fullerene) nanomaterials during simulated wastewater treatment processes. J Hazard Mater 201-202: 16-22.

Wlaser T, Denou E, Lang DJ, Hellweg S (2011) Prospective environmental life cycle assessment of nanosilver T-shirts. Environ Sci Technol 45: 4570-4578.

Wright JB, Lam K, Buret AG, Olson ME, Burrell RE (2002) Early healing events in a porcine model of contaminated wounds: effects of nanocrystalline silver on matrix metalloproteinases, cell apoptosis, and healing. Wound Repair Regen 10: 141-151.

Xu G-N, Qiao X-L, Qiu X-L, Chen J-G (2008) Preparation and characterization of stable monodisperse silver nanoparticles via photoreduction. Colloids Surf. A: Physicochemical and Engineering Aspects 320: 222-226.

Xu J, Li S, Weng J, Wang X, Zhou Z, Yang K et al., (2008) Hydrothermal syntheses of gold nanocrystals: from icosahedral to its truncated form. Addvanced Functional Materials 18: 277-284.

Yamanaka M, Hara K, Kudo J (2005) Bactericidal actions of a silver ion solution on Escherichia coli, studied by energy-filtering transmission electron microscopy and proteomic analysis. Appl Environ Microbiol 71: 7589-7593.

Yang JY, Huang CY, Chuang SS, Chen CC (2007) A clinical experience of treating exfoliative wounds using nanocrystalline silver-containing dressings (Acticoat1). Burns 33: 793-797.

Zhao CM, Wang WX (2011) Comparison of acute and chronic toxicity of silver nanoparticles and silver nitrate to Daphnia magna. Environ Toxicol Chem 30: 885-892.

Zheng Z, Yinb W, Zarad JN, Lib W, Kwakb J, Mamidif R et al. (2010) The use of BMP-2 coupled - Nanosilver-PLGA composite grafts to induce bone repair in grossly infected segmental defects. Biomaterials 31: $9293-9300$. 